onais, voltados para um público-leitor com enorme potencial de expansão no Brasil. Mas, daí a tentar destruir a validade lite-

rária da produção ficcional de uma geração inteira, apenas porque os adolescentes a detestam, vai uma distância enorme. $\mathrm{E}$, ainda, para agravar o caráter preconceituoso da resenha, Felinto nem se digna explicar a presença, em sua lista negra, de autores de best-sellers, como Rubem Fonseca e Fernando Sabino.

Outra generalização pejorativa de Felinto, que igualmente se mostra insustentável, diz respeito aos "mestres" dos ficcionistas citados: todos eles, sem exceção, se inspirariam no Mário de Andrade prosador, e, também, no Machado cronista. Como nem esses improváveis "mestres" são poupados pela articulista, resta aos leitores da Folha lamentar que se lide assim com a tradição literária brasileira, tentando destruir o que pouco se conhece.

Certa vez afirmei que a história da leitura é essencialmente faltosa, porque nenhum leitor leu todos os textos, assim como nenhum texto foi escrito para todos os leitores. Porém, mesmo sem a pretensão de ter lido tudo, cabe ao crítico ler o suficiente para instaurar sua fala num horizonte cultural mais amplo, em que seus próprios leitores se reconheçam e se identifiquem. Nesse ponto, pelo menos, a tão "oficial" crítica universitária ganha em coerên- cia da jomalística: afinal, quais leitores da Folha de fato considerariam Mário de Andrade tão "ruim", Machado tão "superficial", e romancistas contemporâneos como Autran Dourado ou Lígia Fagundes Telles tão "apagados"?

Após esses equívocos lamentáveis, só nos consola saber que a nova obra de Autran Dourado acabará merecendo a atenção de seus verdadeiros leitores virtuais: aqueles amantes do jogo de renovação e tradição, como bons conhecedores dessa grande arte, a literatura, que caminha por "ruas capistranas de toda cor".

\section{ESCRITAS SUPERPOSTAS}

ARÊAS, Vilma. A terceira perna. São Paulo: Brasiliense, 1992.

A escrita mosaico de Vilma Arêas, em A terceira perna, finca alicerce em sofisticado arcabouço teórico, sob a chancela especial da paródia e citação. Especialistas em teoria literária (a própria autora leciona essa matéria na UNICAMP) poderiam citar, ainda, inúmeros outros recursos subsidiários (tais como a intertextualidade, o mise en abyme, a ironia, a alegoria, o fragmento, o relato epistolar, o foco especular, etc.). A partir da metáfora do título - uma terceira perna para voar? indaga a epígrafe-prefácio de Brecht o texto se desvencilha de amarras seculares e instaura um carnavalizado processo de anulação de fronteiras entre o narrativo e o descritivo, entre o relato e o fragmento lírico, entre o ensaio e a crônica. Esta escrita sobre outra escrita, terreno escorregadio onde muitos "rasgam sedas e treinam a medida justa da frivolidade" (p.28), possibilita a criação de uma terceira via de acesso ao invisível: o texto reinventado. Para tanto é preciso acolher a tradição ("as palavras de costume"), acoplar teoria e práxis, círculos e espelhos em (simultânea) interação. Daí que os textos "só podem crescer em círculos" (p.71) e os amantes de "Romeu e Julieta nas águas (furtadas)", embora saibam "que os pássaros devoram as migalhas largadas pelos caminhos e, com sua fome, inventam o labirinto" ... "desejam também a originalidade." (p.74) Ainda que às vezes tendente ao excesso e à retórica, o texto antes se posiciona como espaço de reflexão sobre si mesmo, a um só tempo assumido como ofício lúdico e especular. Aberto ao diálogo e à apropriação de traços de outras linguagens como construção de imagens - cinema, fotografia, pintura. Vejam-se, a propósito, o monumental travelling de "Gruppo de famiglia" e textos como 
"Retrato de Nise da Silveira", "O rosto do herói" e "Nu feminino" entre outros.

O sujeito narrador mantém "conversinhas ao por do sol não apenas com Clarice Lispector, mas também com Drummond, Guimarães Rosa, Dalton Trevisan, Dyonélio Machado, Mário Quintana e Graciliano Ramos. Vale mencionar que as conversas com Guimarães se afastam do mau gosto dos imitadores congêneres (a criação de neologismos). $\mathrm{O}$ sujeito narrador não esconde sua especificidade (a tirania familiar, a servidão) e seu outro rio, o Paraíba do Sul (Cf. "Boi boiada").

Um dos traços mais interessantes dessa escrita concebida como tarefa roedora de outros textos vem expresso na abertura de "Crayon e Grafite", em que o narrador explícito afirma ter escrito uma introdução que acabou não mandando pelo correio (trata-se de uma carta). O texto primeiro (não enviado, mas escrito) deixa no texto segundo suas marcas: afirmar que não envia a introdução não seria uma evidência de que não consegue se livrar de uma lembrança encobridora? Não é esse o mecanismo da libido, substituir as coisas ao invés de eliminá-las?

Mosaico de experimentações _da impressão miúda à crônica, desta ao conto - o texto entrelaça aos fragmentos da memória reiteradas alusões ao corpo (obsessivas em "Estudo a ponta seca" e fluidas nos subseqüen- tes), responsáveis pela sensualidade difusa, às vezes grotesca, em que as pulsões se mostram ambíguas ou intercambiáveis. A aderência ao corpo, pulverizada na segunda parte do livro para dar lugar à paisagem social, não constitui opção pelo erotismo nem elimina a postura crítica, quase sempre atrelada ao componente corrosivo da sátira. Sobretudo quando reivindica, na esteira de Dyonélio Machado, a metáfora dos roedores: "Às três horas em ponto os ratos começam a entrar devagarinho nos poemas e nas cidades." (p.48)

Como os ratos, os autores de textos superpostos não conseguem se desvencilhar da necessidade vital de roer outros textos _- "seus incisivos têm crescimento contínuo." (p.48)

Pode-se falar, em sentido amplo, em terceiro estágio de paródia a propósito do texto de abertura - "Estudo a ponta seca": o contraponto de duas situações se presta à expressão da realidade dual, com intenção satírica. A relação sexual com uma possível empregada doméstica, narrada por um narrador segundo que não consegue apagar detalhes grotescos do primeiro relato (as alusões à cadela Naná, o clássico xingamento de galinha à garota) tem o intento de questionar o preconceito e funciona como espelho de outra relação entre dois irmãos, esta, porém, constrangedora e que se mostra rasurada, com rápidos borrões e indícios no texto/palimpsesto.
Essa técnica de escritas superpostas tendendo ao palimpsesto cultiva a recriação e não escamoteia o gosto pelo texto paralelo. O Aurélio informa que palimpsesto era o pergaminho, usado, em razão de sua escassez ou alto preço, duas ou três vezes, mediante raspagem do texto anterior. A emoção dominada, visível até mesmo nos títulos permeados de tiradas ensaísticas, participa de uma narrativa contemporânea dada à metalinguagem e ao gosto pósmoderno em desreferenciar os fenômenos. $\mathrm{O}$ apagamento do sujeito narrador, decorrência do excesso de construção, torna-se relativo. Aqui e ali ele se revela numa epígrafe, numa dedicatória, num adjetivo aposto a uma citação, numa revolta. Numa constatação amarga _ "nada podemos fazer - por isso escrevemos textos" (p.71). Ou no fascínio por miudezas conceituais: "...também do que se desiste se vive" (p.19), "qualquer que seja a paixão é imoral apenas versejar" (p.28), "não há progresso estético, ou amoroso, sem esquecimento".(p.23) Que não são miudezas assim ("O túnel da memória é de terra solta, escorrem os objetos esquivos do cotidiano", p.96) e se postam como enigmas e palimpsestos, à espera do interesse dos analistas em recuperar o sentido dos borrões originais e ocultos.

Edgard Pereira

UFMG 